\title{
Penerapan Komputasi Alat Ukur Kemampuan Calon Mahasiswa Baru dalam Proses Pemilihan Program Studi
}

\author{
Safitri Jaya ${ }^{1}$, Theofilus Handoyo ${ }^{2}$, Aries Yulianto ${ }^{3}$ \\ 1,2,3Universitas Pembangunan Jaya, Jl Cendrawasih Raya Blok B7/P, Sawah Baru, Kec. \\ Ciputat, Kota Tangerang Selatan, Banten, 15413 \\ 1safitri.jaya@upj.ac.id,ㄹtheofilus.handoyo@student.upj.ac.id, 3aries.yulianto@upj.ac.id
}

Article History:

Received

2021-10-05

Review

2021-12-17

Revised

2021-12-27

Accepted

2021-12-27

Published

2021-12-28
Abstract. Entering the industrial era 4.0, the role of technology in various fields seems to be the prima donna in the decision-making process. Technology is believed to be able to provide acceleration and accuracy in producing information. One of the most dynamic uses of technology can be found in the field of education, namely in the selection of study programs. In general, prospective new students find it difficult to make an option that really suits their abilities. Choices are always influenced by internal and external factors. This of course does not always bring benefits to the prospective student. Many students are found who drop out of studies in the middle of the road due to not being able to follow or obtain good academic achievements. This study tries to approach and measure students' abilities through interest and personality tests. The measurement instrument uses the Holland model and the Big Five Personality. Application development using the Sequential Linear method. The modeling will be converted into a smart computing form so that it is expected to produce a decision recommendation on the suitability between interests and personality with the choice of study program that is in accordance with the abilities possessed by prospective new students.

Keywords: choice of study program, student ability, interest test, personality test

Abstrak. Memasuki era industri 4.0, peran teknologi diberbagai bidang seolah menjadi primadona dalam proses pengambilan keputusan. Teknologi dipercaya mampu menghadirkan percepatan dan ketepatan dalam menghasilkan informasi. Salah satu pemanfaatan teknologi yang sangat dinamis dapat dijumpai dalam bidang pendidikan, yaitu dalam hal pemilihan program studi. Umumnya calon mahasiswa baru sulit untuk menetapkan sebuah pilihan yang benar-benar sesuai dengan kemampuan dirinya. Pilihan selalunya dipengaruhi oleh faktor dari dalam maupun dari luar diri. Hal ini tentunya tidak selalu mendatangkan keuntungan bagi calon mahasiswa tersebut. Banyak dijumpai mahasiswa yang putus studi ditengah jalan akibat tidak mampu mengikuti atau memperoleh capaian akademik yang baik. Penelitian ini mencoba untuk melakukan pendekatan serta pengukuran terhadap kemampuan mahasiswa melalui tes minat dan kepribadian. Instrumen pengukuran menggunakan model Holland dan Big Five Personality. Pengembangan aplikasi menggunakan metode Sequential Linear. Pemodelan tersebut akan dikonversikan kedalam bentuk komputasi pintar sehingga diharapkan dapat menghasilkan sebuah rekomendasi 
keputusan terhadap kesesuaian antara minat dan kepribadian dengan pilihan program studi yang sesuai dengan kemampuan yang dimiliki oleh calon mahasiswa baru.

Kata kunci: pilihan program studi, kemampuan mahasiswa, tes minat, tes kepribadian

\section{Pendahuluan}

Universitas Pembangunan Jaya memberikan kesempatan bagi mahasiswa untuk bisa pindah program studi setelah melewati semester satu. Kesempatan ini hanya diberikan sebanyak satu kali selama menempuh studi di jenjang sarjana. Bagi sebagian mahasiswa kesempatan ini dimanfaatkan dengan alasan ketidakcocokan antara kemampuan mahasiswa dengan program studi yang dipilih ketika awal masuk perguruan tinggi. Ketika menentukan pilihan program studi tersebut, umumnya didasari oleh minat mahasiswa. Akan tetapi berdasarkan pengalaman mahasiswa setelah mengikuti pembelajaran ada hasil yang tidak sesuai dengan target, seperti menurunnya semangat belajar, perolehan IPK yang rendah, bahkan yang fatal beberapa mahasiswa memilih untuk mundur. Setiap tahun terdata sekitar 10 - 20\% mahasiswa yang menemui kondisi seperti ini, dan data tersebut umumnya dijumpai dari sepuluh program studi yang saat ini ada di Universitas Pembangunan Jaya.

Tahun 2017 melalui riset terdahulu yang dilakukan oleh penulis bersama tim, untuk mengenal minat dan bakat calon mahasiswa terhadap program studi yang akan dipilih, dilakukan sebuah pengukuran menggunakan alat ukur psikologi yang mengacu pada model Holland dan IST (Intelligence Structure Test). Pada tahap awal, mahasiswa diberikan kesempatan untuk menentukan sendiri program studi yang akan dipilih, langkah selanjutnya dilakukan pengukuran terhadap tes minat dilakukan dalam tiga tahap sedangkan pengukuran terhadap tes bakat dilakukan dalam satu tahap. Hasil penelitian yang diperoleh menggambarkan adanya perbedaan yang cukup besar antara pilihan program studi yang ditentukan dengan hasil uji minat dan bakat yang sesuai dengan program studi. Salah satu faktor yang membedakan adalah dampak dari pengukuran langsung yang dilakukan kepada setiap calon mahasiswa. Dimana pengukuran dilakukan pada kemampuan sebenar yang dimiliki oleh calon mahasiswa, tanpa adanya kontaminasi dari luar dirinya sendiri. (Safitri.,dkk, 2017).

Alat ukur yang telah dikembangkan sebelumnya masih memiliki peluang untuk dikembangkan lebih lanjut, khususnya dalam tahap pemodelan lebih presisi untuk memperoleh gambaran seperti apa minat mahasiswa dapat digali lebih jauh. Minat tentu 
memberikan gambaran terhadap ketertarikan calon mahasiswa terhadap program studi yang akan dipilih. Minat dapat digali dari tren serapan lulusan oleh dunia usaha dunia industri atau tren lahan pekerjaan yang paling diminati saat ini hingga sepuluh tahun kedepan, disamping adanya keinginan dari orang tua. Bakat memberikan gambaran terhadap kemampuan intelektual yang dimiliki oleh calon mahasiswa yang tentunya menjadi kekuatan dasar untuk menjalani masa studi selama kurang lebih empat tahun di jejang sarjana. Akan tetapi proses penggalian terhadap dua hal tersebut masih dirasa belum maksimal, sehingga pada penelitian kali ini aspek karakteristik atau kepribadian calon mahasiswa turut digali sehingga memberikan gambaran baru terhadap karakter caon mahasiswa dalam mengikuti pembelajaran di sebuah program studi. Karakter ini juga dapat dibandingkan antara satu calon mahasiswa dengan calon mahasiswa lainnya. Dengan adanya pengukuran lanjutan terhadap minat dan karakter yang bersesuaian dapat memberikan gambaran khususnya bagi program studi sebagai pengelola program studi dan mahasiswa untuk dapat memberikan pendampingan dan pembelajaran yang dapat disesuaikan dengan karakter mahasiswanya.

\section{Metode}

Pengembangan model komputasi alat ukur ini dilakukan secara kualitatif. Pendekatan dilakukan terhadap dua keilmuan secara bersamaan yaitu dari keilmuan psikologi dan Informatika. Dari keilmuan psikologi dilakukan beberapa persiapan mulai dari wawancara dengan sepuluh kepala program studi yang ada di Universitas Pembangunan Jaya, pengolahan hasil wawancara, penyusunan draft alat ukur hingga rencana rekomendasi kesesuaian minat dan karakter calon mahasiswa terhadap program studi yang dipilih. Draft alat ukur selanjutnya dikonversi kebentuk numerik supaya data bisa diolah secara komputasi. Sebelum melakukan pengukuran menggunakan sistem alat ukur, seluruh pertanyaan terlebih dahulu diinput kedalam database. Setiap pertanyaan memiliki jawaban supaya memudahkan sistem untuk melakukan proses penilaian. Pilihan jawaban juga dibuat sesederhana mungkin agar peserta tes dapat memahami dengan mudah alur kerja sistem ,dan dapat menentukan jawaban secara cepat dan yakin. Setiap pertanyaan memiliki dua model jawaban yaitu ya dan tidak / setuju dan tidak setuju serta rubrik yang mengadopsi model likert. Setiap jawaban peserta akan dihitung jumlah ya/setuju kemudian dicocoklam dengan pola kesesuaian minat juga karakter. Setiap calon mahasiswa akan mendapatkan dua buah rekomendasi kesesuaian dengan program studi, yaitu rekomendasi berdasarkan hasil tes minat dan rekomendasi berdasarkan hasil tes karakter. Rekomendasi yang dihasilkan tidak bersifat paksaan, artinya setiap calon 
mahasiswa diberikan pilihan untuk menentukan keputusan, apakah mengikuti hasil rekomendasi atau tetap pada pilihan yang dipilih diawal sebelum dilakukannya tes. Lebih lanjut berikut adalah rincian tahapan yang dilakukan dalam penelitian ini :

a. Studi Pendahuluan

Studi pendahuluan merupakan tahap awal dalam pengembangan aplikasi untuk mengetahui masalah, tujuan, dan kelayakan pengembangan aplikasi tes minat dan kepribadian.

b. Waktu dan tempat penelitian

Penelitian ini dilakukan dalam rangka pemenuhan studi pendahuluan serta kebutuhan analisis data untuk pengembangan aplikasi perangkat lunak pada hibah penelitian internal yang dilaksanakan pada bulan November 2020 s.d Oktober 2021 yang berlokasi di Universitas Pembangunan Jaya.

c. Metode pengumpulan data

Metode untuk memperoleh data pada penelitian ini dilakukan melalui beberapa cara sebagai berikut :

1. Wawancara

Dalam hal ini, wawancara dilakukan langsung dengan rekan-rekan dosen dari seluruh program studi di lingkungan Universitas Pembangunan Jaya. Wawancara dilakukan untuk memperoleh data dan informasi terkait kesesuaian kepribadian dengan masing-masing program studi.

2. Observasi

Dalam hal ini, peneliti melakukan pengamatan secara langsung terhadap pengolahan data hasil tes minat dan kepribadian melalui skema alat ukur Holland dan Big Five Personality. Observasi ini dilakukan bersamaan dengan kegiatan wawancara kepada rekan-rekan dosen dari seluruh program studi. Berdasarkan hasil wawancara dan observasi yang dilakukan, diperoleh alur dari pelaksanaan tes minat dan kepribadian hingga hasil olah data dapat diproses sebagaimana yang terlihat pada gambar berikut ini : 


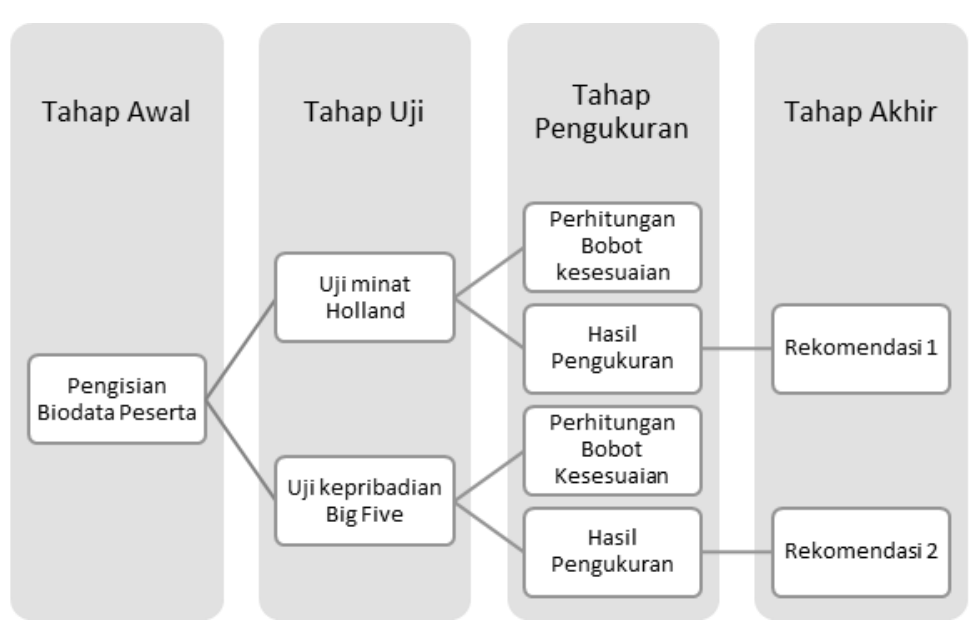

Gambar 1. Alur komputasi alat ukur kemampuan calon mahasiswa baru dalam proses pemilihan program studi

Alur komputasi alat ukur terdiri dari 4 tahap yaitu tahap awal, tahap uji, tahap pengukuran dan tahap akhir sebagaimana yang terlihat pada gambar $1 \mathrm{di}$ atas.

\section{Hasil}

Berikut adalah penjelasan terhadap beberapa hasil yang diperoleh dari penelitian :

1. Identifikasi Kebutuhan Pengguna

Permasalahan yang dijumpai pada saat melakukan tes psikologi adalah bagaimana membuat aplikasi tes minat dan kepribadian yang dapat mengukur serta memudahkan proses pelaksanaan tes, perhitungan, sampai dengan proses penarikan kesimpulan untuk disampaikan kepada calon mahasiswa baru. Semua mekanisme harus dapat berjalan dengan baik dan bersifat rahasia. Hal ini dikarenakan, dalam praktek tes psikologi yang dilakukan secara manual memiliki beberapa poin permasalahan yang menjadi perhatian oleh para ahli. Dari hasil identifikasi kelemahan pelaksanaan tes secara manual, dapat disimpulkan permasalahan yang dijumpai sebagai berikut :

a. Proses pelaksanaan tes membutuhkan waktu yang cukup lama, mulai dari persiapan tes sampai dengan proses penilaian dan penarikan kesimpulan

b. Alat tes yang hanya membutuhkan lembar soal dan lembar jawaban yang sekali pakai, membutuhkan waktu yang lama untuk mempersiapkan bahan-bahan tes serta biaya yang lebih banyak

c. Proses pelaksanaan secara manual membutuhkan tahapan analisa sampai penarikan kesimpulan yang juga harus dilakukan secara manual 
d. Informasi dari skor yang akan sulit ditemukan apabila sewaktu-waktu akan digunakan untuk penelitian karena berhubungan dengan sulitnya penyimpanan data hasil tes

2. Hasil Perancangan Sistem

Pada tahap ini dihasilkan beberapa hasil, diantaranya :

a. Rancangan kebutuhan fungsionalitas aplikasi dan pengguna seperti yang tergambar pada Use Case Diagram pada gambar berikut ini :

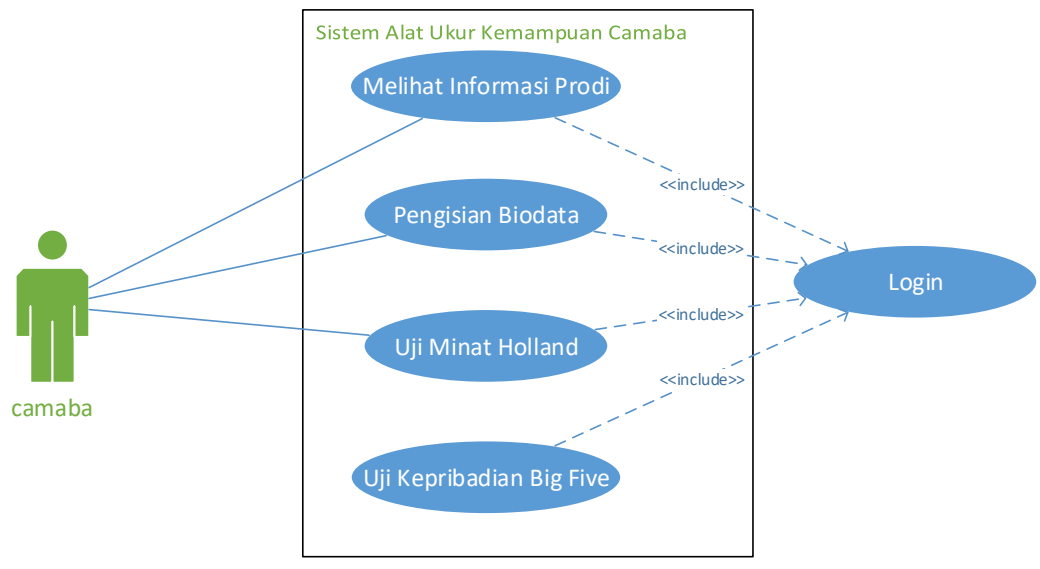

Gambar 2. Use Case Diagram Sistem Alat Ukur Kemampuan Camaba

Rancangan halaman camaba terdiri dari menu lihat informasi prodi, pengisian biodata, tes minat dan tes kepribadian, seperti yang tergambar pada use case diagram yang ada di gambar 2 di atas.

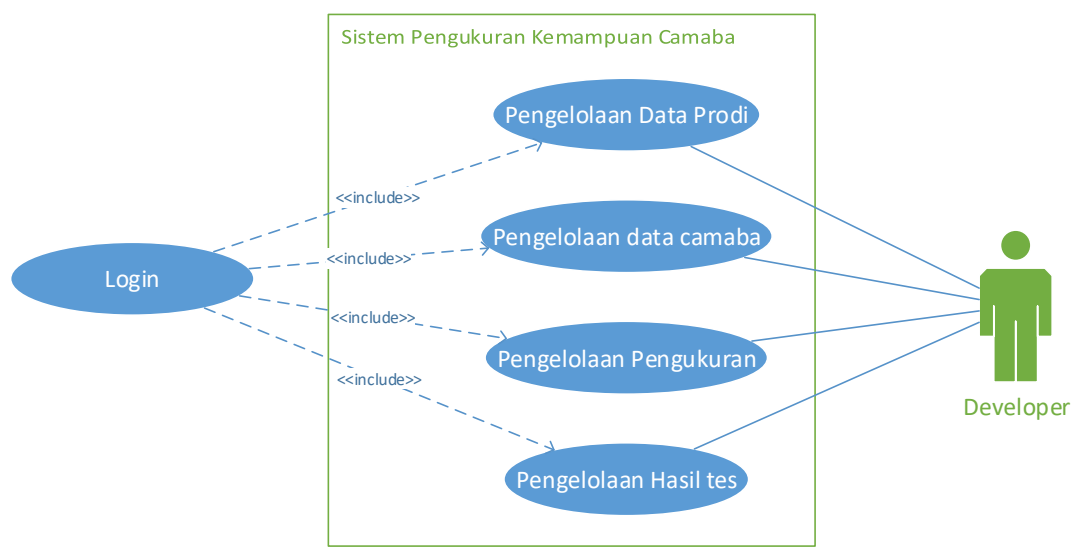

Gambar 3. Use Case Diagram Sistem Pengukuran Kemampuan Camaba (halaman Developer)

Rancangan halaman developer terdiri dari menu kelola data prodi, kelola data camaba, kelola pengukuran tes, dan pengelolaan hasil tes, seperti yang tergambar pada use case diagram yang ada di gambar 3 di atas. 
b. Rancangan perhitungan hasil tes minat dan kepribadian sebagai tahap awal dalam proses penarikan kesimpulan sebagaimana tergambar pada arsitektur pengukuran pada gambar berikut ini :

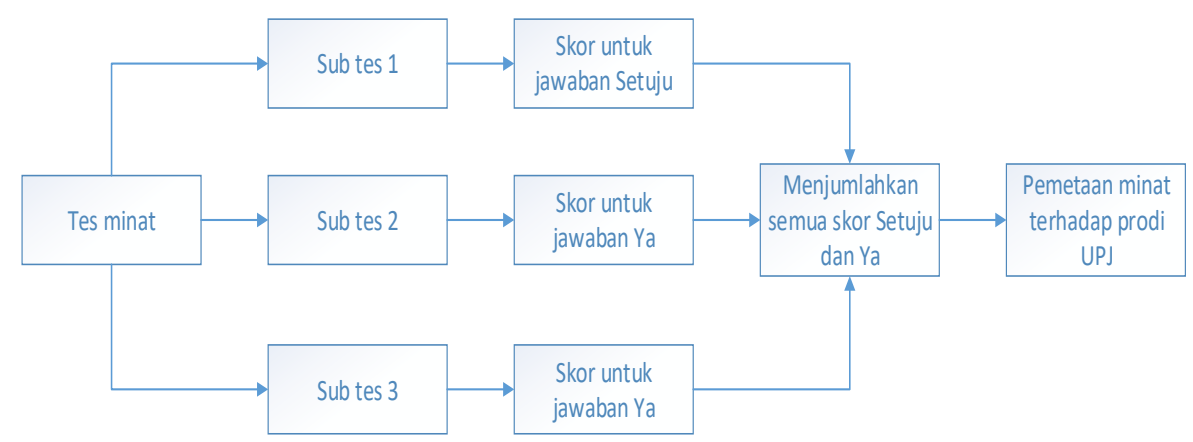

Gambar 4. Arsitektur perhitungan tes minat Holland

Pada gambar 4 di atas dijelaskan bahwa individu mengisi Buklet berhubungan dengan tema model Holland (Realistis, Investigative, Artistik, Sosial, Bersifat Wirausaha, dan Konvensional) yang tersedia pada masing-masing sub tes. Hasil pilihan akan dihitung dan ditotalkan sehingga dapat diperoleh satu kesimpulan minat (Anastasi, Urbina, 2007).

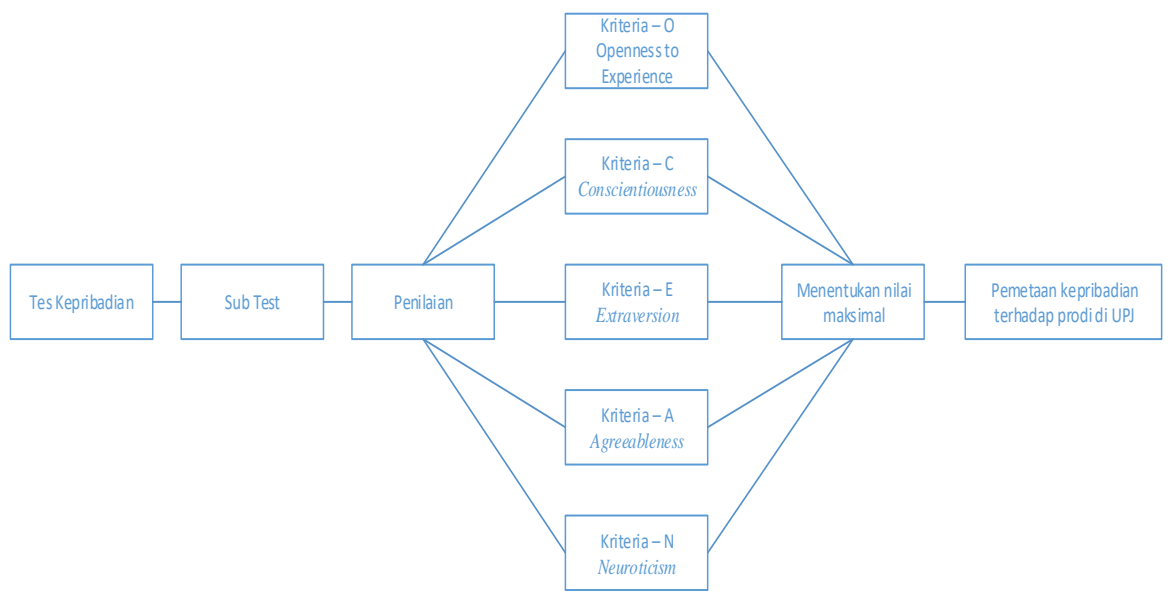

Gambar 5. Arsitektur perhitungan tes kepribadian Big Five Personality

Pada gambar 5 di atas dijelaskan bahwa teori Sifat Kepribadian Model Lima Besar atau Big Five Personality Traits Model terdiri dari 5 dimensi kunci yaitu Openness, Conscientiousness, Extraversion, Agreeableness dan Neuroticism. Setiap pertanyaan akan dihubungkan dengan teori kepribadian, kemudian hasil pilihan akan dijumlahkan untuk memperoleh nilai maksimal sehingga dapat ditarik sebuah kesimpulan. 
3. Hasil Implementasi

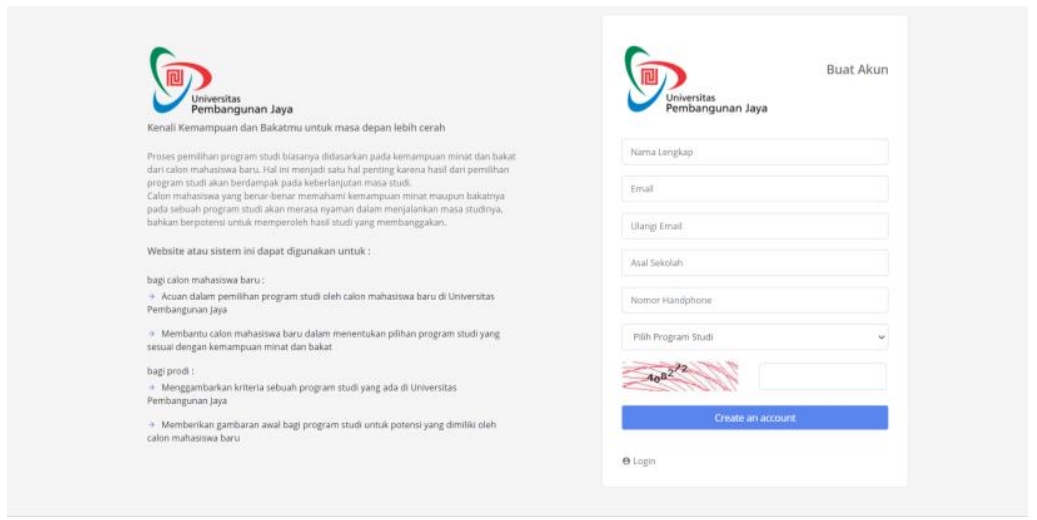

Gambar 6. Halaman Registrasi

Halaman registrasi peserta pada gambar 6 adalah halaman awal yang akan dijumpai oleh peserta (calon mahasiswa baru) ketika ingin mendaftar ke Universitas Pembangunan Jaya. Pada halaman registrasi ini calon mahasiswa baru diminta untuk mengisi biodata singkat yang terdiri dari nama lengkap, email, asal sekolah, nomor telepon, pilihan program studi yang akan dituju (pilihan program studi 1 dan pilihan program studi 2), dan verifikasi captcha. Biodata yang diisikan pada tahap ini cukup sederhana, karena hanya membutuhkan informasi user login untuk digunakan pada halaman berikutnya.

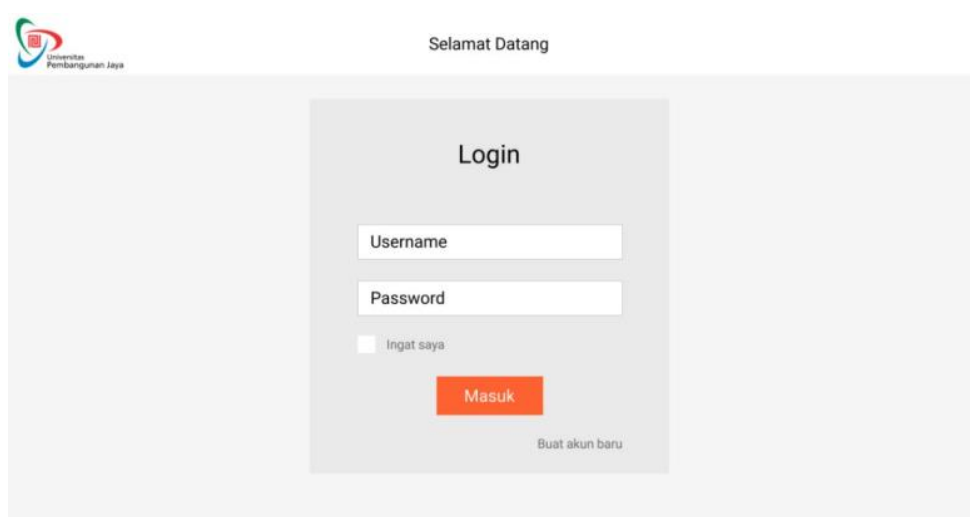

Gambar 7. Halaman Login

Halaman login seperti yang terlihat pada gambar 7 merupakan halaman yang sifatnya individual, artinya yang berhak untuk mengikuti tes hanya pemilik akun. Setiap calon mahasiswa baru akan diberikan halaman privasi untuk mengikuti rangkaian tes yang akan dijalani. 


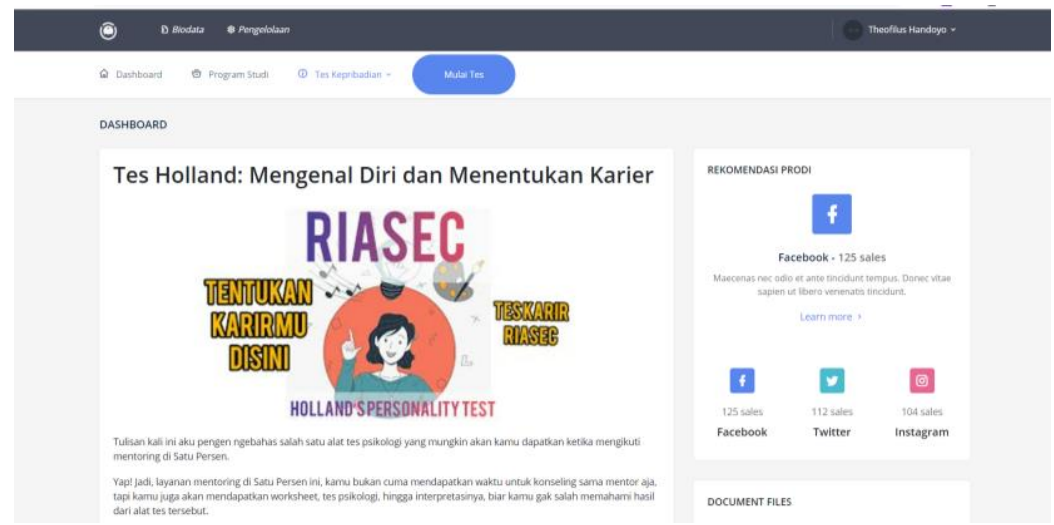

Gambar 8. Beranda Holland

Pada beranda Holland seperti yang terlihat pada gambar 8, merupakan halaman awal yang berisikan pengantar, informasi, dan tata cara menjawab soal tes. Halaman ini dibuat agar pengguna dapat memahami bagaimana menggunakan aplikasi untuk melakukan tes minat.

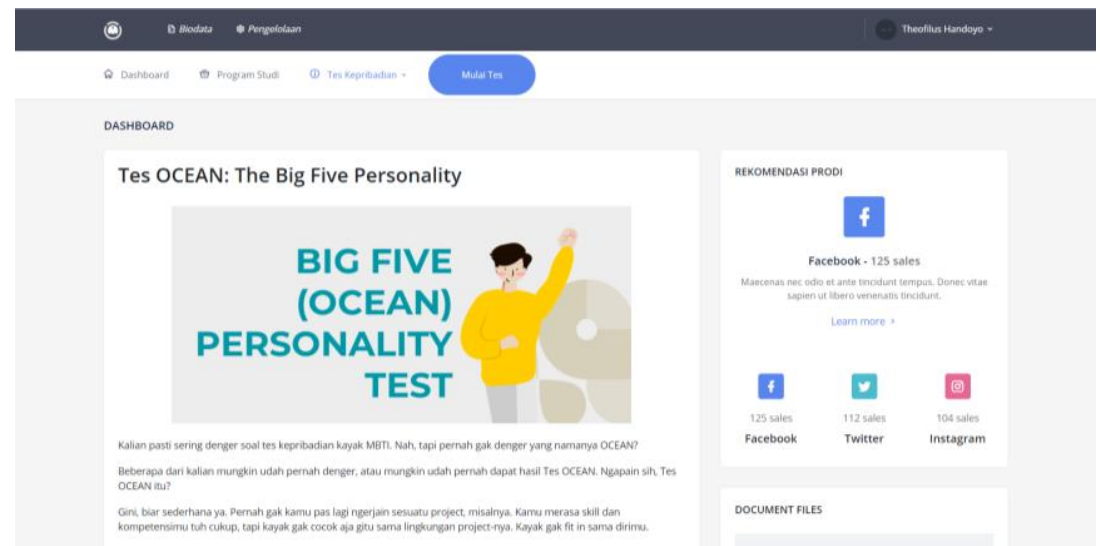

Gambar 9. Beranda Big Five Personality

Pada beranda Big Five Personality seperti yang terlihat pada gambar 9, merupakan halaman awal yang berisikan pengantar, informasi, dan tata cara menjawab soal tes. Halaman ini dibuat agar pengguna dapat memahami bagaimana menggunakan aplikasi untuk melakukan tes kepribadian. 


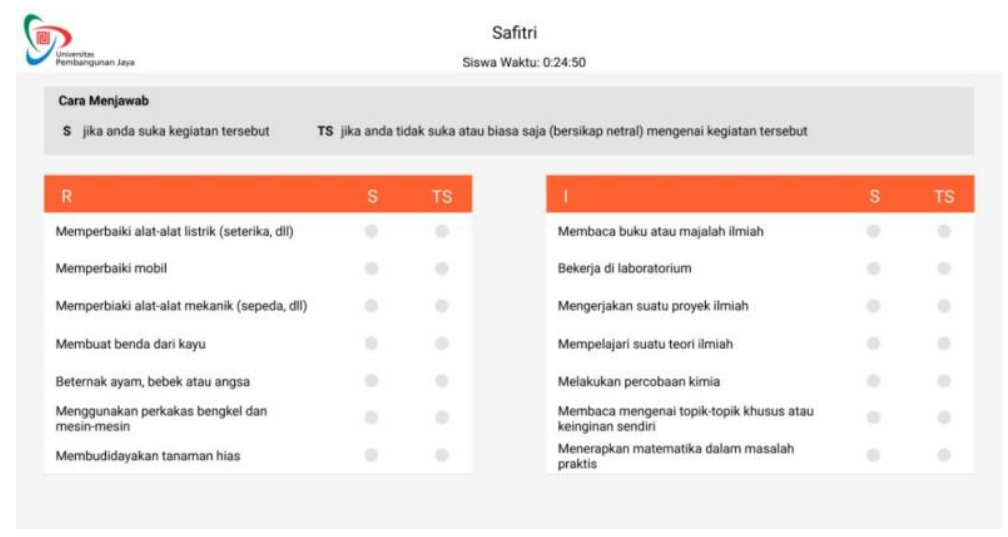

Gambar 10. Halaman tes Holland

Halaman tes Holland seperti yang terlihat pada gambar 10 adalah halaman tes tahap 1 yang akan diberikan kepada calon mahasiswa baru. Halaman tes Holland terdiri dari 3 (tiga) sub test yaitu konsistensi, diferensiasi dan kongruensi. Masing-masing sub tes menggambarkan kesesuaian dengan 6 karakteristik penilaian yaitu Tipe Realistik (The Realistik Type), Tipe Peneliti/Pengusut (The Investigative Type), Tipe Seniman (The Artistic Type), Tipe Sosial (The Social Type), Tipe Pengusaha (The Enterprising Type), dan Tipe Konvensional (Conventional Type). Masing-masing karakteristik memiliki kesesuaian dengan program studi di Universitas Pembangunan Jaya.

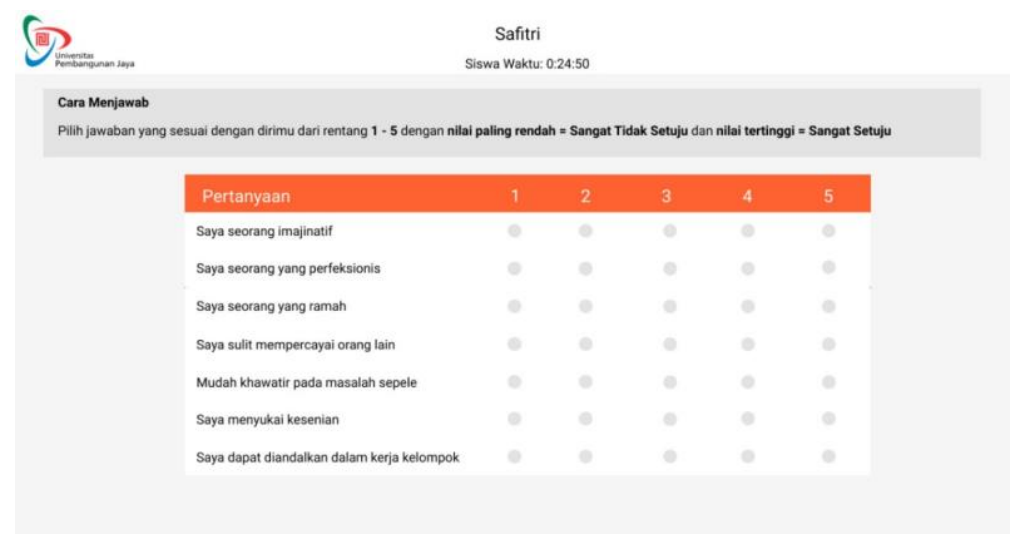

Gambar 11. Halaman tes Big Five Personality

Halaman tes Big Five Personality seperti yang terlihat pada gambar 11 adalah halaman tes tahap 2 yang akan diberikan kepada calon mahasiswa baru. Berbeda dengan model Holland yang hanya memiliki pilihan jawaban YA dan Tidak atau Setuju dan Tidak Setuju, pada model Big Five setiap butir pertanyaan memiliki tingkat kesesuaian yang dapat bisa dipilih dengan skala 1 untuk nilai paling rendah/paling tidak setuju sampai dengan skala 5 untuk nilai paling tinggi/sangat setuju. Skor akhir diperoleh dengan cara menjumlahkan hasil skor dari soal pertama sampai dengan soal terakhir. Setiap penilaian 
menggambarkan kesesuaian dengan salah satu kriteria yaitu Openess, Conscientiousness, Extraversion, Agreeableness, dan Neuroticism.

\section{Diskusi}

Keutamaan penelitian ini adalah menghasilkan pola baru dalam mengenali sejauh mana kesesuaian antara pilihan pertama yang ditentukan oleh calon mahasiswa baru pada saat melakukan pendaftaran, dengan hasil pengukuran terhadap minat dan karakter yang diperoleh dari hasil tes. Komputasi ini dikemas dalam bentuk website sehingga memudahkkan calon mahasiswa untuk mengikuti proses tes. Website yang dimaksud dapat dikunjungi melalui Login Page (seleksi-maba.com).

\section{Simpulan}

Berdasarkan hasil penelitian yang diperoleh saat ini, dapat disimpulkan bahwa rancangan purwarupa memiliki tampilan yang user friendly serta navigasi sistem yang sistematis. Rancangan pemodelan yang digunakan sebagai dasar pengukuran bersifat sederhana, terukur dan sesuai dengan kriteria mahasiswa yang dimiliki oleh program studi. Pemodelan Holland dan Big Five Personality terbukti dapat membantu proses komputasi dalam melakukan pengukuran kemampuan calon mahasiswa baru dalam proses pemilihan program studi di Universitas Pembangunan Jaya. Rekomendasi yang dihasilkan dari hasil pengukuran pada aplikasi ini tidak bersifat memaksa, dalam arti keputusan akhir tetap diserahkan kepada calon mahasiswa baru dalam menentukan pilihan. Rekomendasi ini setidaknya dapat memberikan gambaran kemampuan yang dimiliki oleh calon mahasiswa baru dalam mempersiapkan diri untuk melanjutkan studinya di perguruan tinggi, khususnya di Universitas Pembangunan Jaya, karena hasil rekomendasi secara khusus sudah disesuaikan dengan masing-masing program studi yang ada.

\section{Saran}

Minat merupakan suatu ketertarikan seseorang terhadap satu obyek tertentu. Untuk dapat menggali potensi minat khususnya dalam proses pemilihan program studi tentu difaktori oleh beberapa hal. Penelitian ini memiliki peluang yang besar untuk dapat dikaji lebih dalam, baik dari keilmuan psikologi maupun Informatika. Rekayasa sistem dapat menghasilkan purwarupa baru dalam melakukan pengukuran kemampuan calon mahasiswa baru, seperti penentuan minat menggunakan sistem jaringan syaraf tiruan 
yang dapat digunakan untuk memodelkan hubungan yang lebih kompleks antara input dan output untuk menemukan pola-pola pada data minat calon mahasiswa baru.

\section{Kepustakaan}

Jaya, Safitri., dkk (2017). Seminar Nasional Sains dan Teknologi, Fakultas Teknik Universitas Muhammadiyah Jakarta, p- ISSN : 2407 - 1846 "Sistem Pemilihan Program Studi Berdasarkan Bakat, Minat Dan Kecerdasan Calon Mahasiswa Berbasis Online"

Anastasi, A \& Urbina. (2007). Tes Psikologi: Terjemahan. Jakarta: PT Indeks

Ramdhani (2012). Adaptasi Bahasa dan Budaya dari Skala Kepribadian Big Five. Jurnal Psikologi, Vol.39. No. 2

Guilford, J.P. (1956). Fundamental Statistic in Psychology and Education. 3rd Ed. New York: McGraw-Hill Book Company, Inc.

Osipow, Samuel H (1983). Theories of Career Development. The Ohio State University, New Jersey

Winkel, W.S \& Sri Hastuti (2005). Bimbingan dan Konseling di Institusi Pendidikan .

Jakarta: PT. Grasindo 